\title{
Med humanističnim in poklienim izobraževanjem ali kaj terja od nas prihodnost
}

\author{
Dušana Findeisen
}

Dobro izobraževanje ni prema črta, ki brez ovinkov vodi $k$ cilju. Človekovo notranje
bogastvo in njegova ustvarjalnost sta namreč odvisna od marsičesa »nepotrebnega«.

Misel sodobnega francoskega slikarja

\begin{abstract}
$\mathrm{V}$ prispevku obravnavam razmerje med humanističnim in poklicnim izobraževanjem. V prvem delu govorim o lastnostih in ključnih usposobljenostih odraslih in o povezavi slednjih z izobraževanjem. V nadaljevanju obravnavam posledično potrebo po drugačnem ocenjevanju, in potrebo po hkratnem uravnovešenju učnih vsebin in didaktičnih postopkov. V naslednjem delu se ukvarjam $\mathrm{z}$ vprašanjem splošne izobraženosti $\mathrm{v}$ podjetjih, saj je dobra usposobljenost za razvoj odvisna od ljudi, ki se znajo prilagajati nenehnemu razvoju podjetja. Nato opozarjam na nepotrebnost prezgodnjega usmerjanja mladih ljudi, ki se morajo naučiti negotovosti, ki jih bo spremljala skozi življenje. V zadnjem delu prispevka pa načenjam vprašanje izmeničnega učenja v izobraževalnih ustanovah in podjetjih in se zavzemam za odpravljanje prepada med višjo in visoko šolo, med splošnim in poklicnim izobraževanjem, med začetnim in permanentnim izobraževanjem.
\end{abstract}

\section{Uvod}

Za šolo od sedemnajstega stoletja dalje, ko ji cerkev nalaga tudi vzgojno funkcijo, velja, da izpolnjuje predvsem tri naloge: poučevanje, vzgojo in socializacijo. Res je bilo poslanstvo šole sprva omejeno na poučevanje in res je bilo v poučevanju zmeraj razmeroma laže določiti cilje in dokaj preprosto preveriti, ali so učni napori prinesli sadove. Poklicni uk je imel namreč to prednost, da ga je bilo mogoče usmeriti v pridobivanje določnih in opredeljivih znanj ter spretnosti. Tako se je včasih šola lahko zadovoljila s tem, da je izobraževala za poklice, ki so se jih kasneje ljudje zares naučili opravljati izkustveno, z delom. Poleg tega so izbrani poklic večinoma opravljali celo življenje.

Zlasti to slednje ne velja več. Raziskave kažejo, da bodo ljudje tudi v evropskem prostoru povprečno petkrat v življenju zamenjali poklic. Zato morata biti danes šolanje in nenehno izobraževanje nasploh drugačna, zvesta drugačnim načelom. Predvsem imata dvojno funkcijo: funkcijo splošnega in funkcijo poklicnega izobraževanja.

\section{V prihodnje bo poudarek na ljudeh}

Ob tem se nam vsiljuje bistveno vprašanje; kdo, in če sploh, je sposoben z gotovostjo predvideti kakšne kvalifikacije bodo potrebne čez petnajst let, ko bodo učenci prišli iz šole na trg dela. Čas miru in gotovosti je daleč za nami. Z gotovostjo lahko od- govorimo le, da bosta čez petnajst let, tudi čez petnajst let, naše gospodarstvo in naša družba potrebovala ljudi. Kakšne ljudi? Na to vprašanje Jack Lang, bivši francoski minister za kulturo, odgovarja, rekoč, da bodo morali biti moralno trdni, sposobni, usposobljeni, kultivirani, prilagodljivi, odgovorni in socialno mobilni. Dodali bi, da naj bodo usposobljeni za samostojno učenje. Takšne lastnosti pa so vprašanje poučevanja, vzgoje in socializacije hkrati. Podobno razmišlja John Dewey:

»Splošno znano je prepričanje, da vzgoja in izobraževanje ne zastaneta s koncem šolanja. Tako je namen šolskega izobraževanja, da zagotovi tudi nadaljevanje izobraževanja, in sicer tako, da omogoči vzpostavitev tistih sil v človeku, ki zagotavljajo njegovo rast. Nagnjenost do učenja iz samega življenja« (podčrtala D. F.) /.../ »je najboljši nasledek šolanja.« (Dewey 1966, str. 51)

Prepričanje, da se vrednost izobrazbe meri po človeku, ki ga pomaga ustvariti, je močno razširjeno, še posebej pri francoskih mislecih. O ljudeh kot o nasledku vzgoje in izobraževanja pišejo tudi drugi, še posebej nemški sociologi, ko govorijo o t. i. ključnih kvalifikacijah ali morda slovensko ključnih usposobljenostih. Te ključne usposobljenosti, med katere uvrščamo tako usposobljenost za obvladovanje osnovnih miselnih procesov kot usposobljenost za ustno in pisno sporazumevanje, pa tudi izoblikovanje stališč na raznih področjih življenja v skupnosti, tudi tisti globalni. Sem sodijo še usposobljenost za strpnost do drugačnosti, do drugih religij, odnos do okolja itd. Še več, te ključne usposobljenosti so bistveni cilji šolanja in izobraževanja odraslih, ki jih morajo načrtovalci in izvajalci izobraževalnih programov imeti pred očmi kot cilje, ki jih je treba doseči in jih vplesti med druge cilje izobraževalnih programov. Seveda ni dovolj, da takšne cilje zgolj postavijo. Ti cilji narekujejo tudi drugačne didaktične postopke in drugačno ocenjevanje.

\section{Drugačno ocenjevanje, uravnovešene učne vsebine in posfopki}

$\mathrm{S}$ francosko revolucijo se pojavljajo zahteve po šolanju za vse (kar pomeni tudi potrditev javnih pravic in javne oblasti), po pripravi za natančno opredeljene socialne funkcije (kar uvede $v$ šolanje specializacije in izobraževanje za poklice). Uvaja se tudi priznavanje osebnih zaslug, kar posebej vpliva na ocenjevanje. Leta 1808 je oblast uvedla maturo, to je bilo takrat, ko je ustanovila tudi liceje in nove univerze, da bi tako zagotovila vse potrebno za »večino poklicev v družbenem in političnem življe- 
nju«. Maturanti se tedaj ne posvečajo nadaljnemu univerzitetnemu šolanju, marveč postanejo Napoleonovi državni funkcionarji ali vojaki in tako stopajo v središče družbenega življenja. Posledično se krepi tudi državni nadzor nad maturo.

V devetnajstem stoletju so se šolski sistemi razvejali, pojavili so se izpiti, diplome, ki naj utrjujejo povezavo med poučevanjem in družbo. $Z$ razvojem plačane delovne sile se javlja tudi trg dela in veča se pomen določanja višine plač in njihova hierarhija. $\mathrm{Na}$ področju dela se pojavlja delovni sistem, v katerem prihaja do delitve del in do funkcionalne soodvisnosti posameznih dejavnosti, kar povzroča tudi razporejanje ljudi v poklice in hierarhijo delovnih mest. Takšno družbeno stanje odseva tudi ocenjevanje izobraževanja.

Način ocenjevanja ljudi na mestih, kjer se oblikujejo in preoblikujejo, je tako posledica družbenega stanja in družbenega razvoja. Vprašajmo se tedaj, kakšno družbo imamo danes in kakšno pričakujemo v prihodnje, kakšna je in bo vloga posameznika $\mathrm{v}$ tej družbi, kako bo ta posameznik živel in delal. V času sprememb, ko se rahlja nekdanja družbena sestava, ko je celo zakonodaja negotova in nedovršena, ko se gradi civilna družba, ki predvideva večjo neodvisnost ljudi od države, ko se s številnimi novimi viri učenja (internet, CD-romi itd.) in številnimi samostojnimi oblikami učenja (izobraževanje na daljavo itd.) spreminjajo odnosi med ljudmi iz hierarhičnih v sodelujoče, potrebujemo drugačne ljudi. Drugačne ljudi potrebujemo tudi zato, ker je delovna soodvisnost drugačna. Futurologi napovedujejo razširitev drugačnega načina proizvajanja, kjer bo vsakdo moral iskati rešitve in sprejemati odločitve, saj bo sam odgovoren za svoje delo. Nad njim ne bo »nadpostavljenega«, ki bi mu s položaja avtoritete dajal povratne informacije o kakovosti njegovega dela. Tudi o tem bo posameznik moral razmišljati sam. Zato bo prisiljen že med šolanjem razviti lastna notranja merila in sodila. Da pa bi bilo to mogoče, bo moral razviti tudi primerne osebnostne lastnosti in doseči posamezne splošne usposobljenosti. Prav razvoj teh osebnostnih lastnosti in splošnih usposobljenosti med izobraževanjem pa zahteva drugačne didaktične postopke in drugačno ocenjevanje. Slednje nedvomno ni preprosto, saj je splošne usposobljenosti težje meriti kot določna in opredeljiva znanja.

Naše gospodarstvo in naša družba bosta potrebovala uravnovešene ljudi, zato mora biti tudi današnje izobraževanje uravnovešeno. In kaj to pomeni? Imeti mora sestavine, ki takšno uravnovešenost zagotavljajo. Zato ni več mogoče povsem poklicno ali povsem humanistično izobraževanje. ${ }^{1}$

Na pragu 21. stoletja, ki bo najverjetneje izjemno težko, zdaj ko Evropa doživlja korenite spremembe, ne gre več preprosto za reformo šole. Namreč, že dolgo zna šola vzgajati, pripravljati na poklic, oblikovati človekov duh. Gre bolj za to, da se v učnih postopkih bolj ovemo velikih zahtev, ki jih postavljata delo in življenje, in da posledično tudi učne vsebine in postopke uravnovesimo.

\section{Humanistične sposobnostii v podjetiih}

»Prepričan sem, « pravi Lang, »da se naša podjetja ne morejo zadovoljiti s tem, da si poiščejo sposobne strokovnjake, ki pa se niso sposobni prilagajati...« (Lang) Sleherno podjetje izobražuje svoje ljudi, vanje vlaga denar, upanje, energijo. Še več, sleherno

\footnotetext{
1 Po desetih letih funkcionalnega jezikovnega usposabljanja zaposlenih $v$ neki naši tovarni, se tako zdaj srečujemo $\mathrm{z}$ novo prevladujočo zahtevo po učenju jezika, ki vodi v osebnostni razvoj, pomaga razumevati življenje in delo, vzpostavljati boljše sporazumevanje s socialnim okoljem. Nedvomno je v tem prepoznati odziv na neuravnovešenost poklicnega in splošnega izobraževanja.
}

podjetje se neprestano razvija. Zato je verjetno v prid takšnega podjetja, da zaposluje ljudi, ki se lahko razvijajo skupaj z njim, bolj kot da sili v brezposlenost tiste, ki se ne morejo prilagoditi njegovim potrebam. Čedalje bolj bodo podjetja potrebovala ljudi, ki bodo sposobni prilagoditi se novim tehnološkim postopkom, privzeti nove načine organizacije poslovanja, delati $z$ drugimi, izmenjati svoja znanja in izkušnje, torej odprte ljudi, ki se bodo sposobni sporazumevati s socialnim okoljem. Družba pa bo najverjetneje potrebovala tudi ljudi, ki bodo sposobni živeti v skupnosti. Skupnost, če naj verjamemo Deweyu, pa ne obstaja, če ni v njej razvite komunikacije, pisne in ustne. Le z obladovanjem komunikacije skupnost zares poseduje tisto, kar ima skupnega, kar jo povezuje: interese, potrebe, aspiracije. Usposobljenost za sporazumevanje je tako ena ključnih usposobljenosti, ki jih bo potreboval človek prihodnosti.

Sicer pa v podjetjih čedalje bolj zahtevajo splošno izobraženost. Na to kažejo tudi rezultati raziskave Eurodelphy raziskave, ki je za Slovenijo pokazala, da je največ inovacij v izobraževanju odraslih prav na področju razumevanja in obvladovanja medosebnih odnosov in sporazumevanja ter na področju raznih izobraževalnih oblik z vsebinami, namenjenimi ne več ozko poklicu, marveč življenju. Takšna splošna izobraženost je namreč porok za to, da se bo delavec sposoben povezovati z drugimi, z njimi sodelovati. Pomeni tudi močno motiviranost za delo, dobre sposobnosti prilagajanja. Čedalje bolj, čeprav tega morda ne izrazijo, direktorje podjetij zanimajo sposobnosti, ki se razvijejo s splošnim izobraževanjem. Sleherno podjetje naj bi tako zaposlovalo delavce, ki bodo tako humanistično kot naravoslovnotehnično izobraženi. Navsezadnje pa je dobra osebna izobraženost osnova za kasnejšo specializacijo. Takšno usposobljenost za razvoj lahko dosežemo. Razviti osebnost ljudi je namreč prav tako poslanstvo izobraževalnega sistema.

Tisti, ki so mladi, pa so v današnjem nemirnem in negotovem svetu posebej izpostavljeni, saj je celoten izobraževalni sistem naravnan tako, da se je ves čas potrebno odločati med pravimi in nepravimi možnostmi. To velja za vse stopnje šolanja, od srednje pa do fakultete. Mlad človek, ki se zaradi teh ali onih razlogov vpiše na neko šolo, si že utira pot v prav določeno smer. Vendarle, koliko in kako dolgo bo ta smer prava, ni mogoče z gotovostjo napovedati.

\section{Nepolrebna in prezgodnja usmerjenost izobraževanị}

Neravnovesje zaznavamo marsikje $v$ izobraževanju. Spominjam se, da so nekoč, še v času Federativne Jugoslavije, mladi v Beogradu težko našli prvo zaposlitev. Zato so se trli na predavanjih tretjestopenjskega študija, število magistrov je raslo iz dneva v dan. Podaljševali so svoj študij, pogosto brez posebnih stremljenj in brez potrebnih poklicnih izkušenj, potrebnih za pravo raziskovanje. Podobno se zdaj dogaja v zahodnih deželah. Ponekod je tako tudi zato, ker imajo mladi $\mathrm{z}$ več diplomami več možnosti, da jih sprejmejo v svet zaposlenih. Tako je npr. v Franciji 70\% mladih pri devetnajstih v šolah. Tega bi se lahko le veselili, pravi Jack Lang, če ne bi šlo bolj za brezglavo dirko naprej kot za razsoden izbor pravih možnosti. Kajti, če mislimo, da je splošna izobraženost brez prave priprave na poklicno življenje dovolj, se lahko zgodi, da se splošno izobraževanje zavleče $\mathrm{v}$ nedogled. Trenutek prestopa $\mathrm{v}$ svet zaposlenih bo tako zmeraj bolj oddaljen. Tako se mnogi znajdejo izrinjeni iz študijske poti, brez diplom, saj so se bili podali na pot, ki jih ni privlačila, saj niso v pravem trenutku prišli do pravih odločitev glede tega, kaj bodo študirali. 
Zdi se, da je v našem izobraževalnem sistemu vprašanje dobrih in pravih odločitev še zmeraj bistvenega pomena. Zato bi bilo treba mladim ob vstopu v srednjo šolo pomagati, da oblikujejo svoje lastne, osebne poglede na svojo študijsko pot, da se bodo zavedli prednosti in pomanjkljivosti svojih odločitev glede na osveščene želje in potrebe. $\mathrm{K}$ temu bi pripomogli strokovnjaki in profesorji, orientacijski svetovalci, ki bi prišli v osmi razred osnovne šole in dodobra predstavili mladim posamezne poklice in njihove zahteve na zanimiv in razumljiv način.

Podobne svetovalne službe bi potrebovali tudi v izobraževanju odraslih. Priključiti bi jih bilo mogoče vsem ustanovam, kjer izobraževanje odraslih že poteka, fakultetam, izobraževalnim službam v podjetjih. Ustanovili bi lahko, t. i. forume poklicev, kjer bi vsako leto prikazali vrsto poklicev, in znova razmislili o tem, kakšna poklicna znanja in kakšna splošna usposobljenost je potrebna za opravljanje posameznih poklicev ali za širše poklicno delo.

V Franciji je na primer v zadnjih dvajsetih letih število maturantov srednjih tehniških in poklicnih šol naraslo, se podvojilo. To si Francozi razlagajo tako, da se v srednjih tehniških šolah bolj posvečajo mladim, da je odnos do njih osebnejši, saj so razmere, v katerih se učijo, boljše ( 23 učencev proti 31 v splošnoizobraževalnih razredih). Praksa v podjetjih in izmenično učenje v šoli ter v podjetju bolje pripravita mlade na vstop v svet dela ali na iskanje zaposlitve. Dodatno humanistično izobraževanje, ki se vse bolj uveljavlja na srednjih tehniških šolah, nadalje omogoča boljšo prilagodljivost za kasnejši dodatni študij. Poleg tega mnoge naravoslovno-tehniške fakultete vključujejo med predavatelje mnoge strokovnjake iz prakse.

Pri vsem tem je mladim treba prepustiti možnost, da se iščejo, preizkušajo, se razvijajo, si poiščejo svoje lastne poti. V današnjem svetu to ni več povsem preprosto. Na področju izobraževanja razvoj družbe prepoveduje ozko utirjene poti. Glede na to, da je negotovost stalna spremljevalka mladih, bi želeli, da bi bilo njihovo izobraževanje bolj odprto, manj opredeljeno, da bi bile možne mnogotere povezave med posameznimi študijskimi predmeti, med humanističnimi in naravoslovno-tehniškimi predmeti, da bi bile mogoče povezave med splošnim izobraževanjem in poklicnim izobraževanjem, med krajšim in daljšim univerzitetnim študijem. Predvsem pa z nobenim zakonom ne bi smeli mladim preprečiti, da gredo dalje, da pridejo tja, kamor so sposobni prispeti. Eden takšnih nesmislov, ki bi jih morali čim prej odpraviti, je numerus clausus, ki ga nekateri avtorji obravnavajo kot sadizem nad lastnim narodom, ali pa zahteva po visoki povprečni oceni na dodiplomskem študiju, ki ostaja pogoj za vpis na tretjo stopnjo univerzitetnega študija. Študentu, ki si je pridobil diplomo druge stopnje, moramo že z samo podelitvijo diplome priznati usposobljenost za nadaljevanje študija. Če ravnamo drugače, pa to pomeni, da zanikamo tudi vrednost že pridobljene diplome in študentovo splošno usposobljenost, ki smo jo $\mathrm{z}$ dodiplomskim študijem dolžni razviti.

\section{Kie in kako odseva iskanje ravnovesja v izobraževanju}

Takšno iskanje ravnovesja najde odsev v učenju, ki poteka nekaj časa v šolah in nekaj časa v podjetjih. Mnoge splošnoizobraževalne šole se povezujejo in pobratijo z lokalnimi podjetji. Takšno izmenično učenje naj bi bilo odraz novega ravnovesja med vzgojo in izobraževanjem, med splošnim in poklicnim izobraževanjem, med humanističnimi in naravoslovnimi vedami. Čemu ne bi v poklicno izobraževanje vključili obdobij učenja, posvečenih kulturi, izpopolnjevanju samega sebe, osebnostni rasti?

Izmenično učenje $v$ šoli in podjetju naj bi zgladilo tudi neravnovesje med začetnim in permanentnim izobraževanjem, kajti večina bistvenih stvari se pri naših ljudeh še zmeraj zgodi v obdobju začetnega in ne permanentnega izobraževanja. Odrasli Francozi se tako v povprečju formalno izobražujejo manj kot petdeset ur letno. Od 20. julija 1992 francoske šole priznavajo, da tudi podjetja lahko izobražujejo in šola zato lažje priznava dosežke poklicnega življenja in jih verificira. Po zdajšnjih zakonih se bodo tisti s poklicnimi izkušnjami, ki naj ustrezajo znanjem, ki jih verificira spričevalo srednje šole, lahko vpisali na fakultete.

Da bi se prilagodili razvoju podjetij, da bi mladim dali dovolj časa, da najdejo svoje mesto v družbi, ki je čedalje bolj zahtevna, se mora vzpostaviti drugačen, nov izobraževalni sistem, v katerem ne bo prepada med višjo in visoko šolo, med splošnim in poklicnim izobraževanjem, med začetnim izobraževanjem in permanentnim izobraževanjem.

\section{Sklep}

Razmišljanje o splošni usposobljenosti mladih in odraslih, o razmerju med humanističnim in poklicnim izobraževanjem se znova glasneje oglaša ob vzpostavitvi kurikularnih komisij, odgovornih za prenovo programov v našem izobraževalnem sistemu. Preden znova preučimo programske vsebine, razmislimo o tem, kakšne ljudi potrebujemo in posledično tudi kakšno družbe si želimo. Na katerih vrednotah, poleg tržnih, bo slonela. Če jo bomo oprli na vrednote, kot so prilagodljivost, sposobnost sodelovanja in prispevanja, občutljivost za lastne potrebe in potrebe drugih, podvzetnost, odgovornost, kultiviranost, moralna trdnost, ustvarjalna kritičnost duha itd., če bomo hoteli imeti dejavne in ne podrejene državljane, bomo v kurikularni prenovi izobraževanja odraslih razvoju splošnih usposobljenosti dali mesto, ki si ga zasluži. Posledično bo splošno, humanistično izobraževanje dobilo primernejšo vlogo. Prodrlo bo v »ozkotirno« usposabljanje, pojavile se bodo potrebe po zgolj splošnem izobraževanju, namenjenemu ne delovnemu procesu, marveč človeku, ki takšen proces načrtuje, vodi in ga obvladuje.

\section{Dušana Findeisen}

Logos - jezikovno izobraževanje - Skupina svobodnih izobraževalcev

\section{Literafura}

Vers de nouveaux équilibres, v: Education et économie št. 16, 1992, str. 24

Barbier, J.-M.: L'évaluation en formation, PUF, Paris, 1985.

Courtney, S.: Why Adults Learn, Routledge, London, 1992.

Dewey, J.: Democracy and Education, Macmillan, New York, 1966.

Findeisen, D.: Condorcetov prispevek k razmišljanju o vlogi učenja v človekovem in družbenem življenju, v: Andragoška spoznanja, št. 3-4, 1995.

Lengrand, P.: Uvod u permanentno obrazovanje, BIGZ, Beograd, 1976.

Reboul, O.: La philosophie de l'éducation, PUF, Paris, 1988.

Wain, K.: Philosophy of Lifelong Education, Croom Helm, London. 